\title{
Akibat Hukum Perkawinan di Bawah Tangan terhadap Istri, Anak, dan Harta Kekayaan dalam Perspektif Hukum Islam dan Undang-Undang Nomor 1 Tahun 1974 Tentang Perkawinan
}

\author{
Nurhasan $^{1}$, Fitri Yani ${ }^{2}$ \\ Fakultas Hukum Universitas Batanghari \\ Jalan Slamet Riyadi, Broni, Kota Jambi (0741) 65351 \\ Email : fitriyaniasmari@gmail.com
}

\begin{abstract}
Abstrak. Perkawinan merupakan bagian hidup yang sakral, karena harus memperhatikan norma dan kaidah dalam bermasyarakat. Namun karena berbagai macam alasan, perkawinan sering dilakukan dalam berbagai macam model Pernikahan. Seperti Perkawinan di bawah tangan. Perkawinan di bawah tangan adalah perkawinan yang telah memenuhi rukun dan syarat perkawinan akan tetapi belum mencatatakan perkawinan tersebut pada instansi yang berwenang sebagaimana yang telah di tetapkan dalam peraturan perundang-undangan. Tujuan penelitian ini adalah mengungkapkan akibat hukum hasil perkawinan dibawah tangan terhadap istri, anak dan harta kekayaan dari Hukum Islam dan Undang-Undang Nomor 1 Tahun 1974 Tentang Perkawinan dengan harapan agar timbul kesadaran setiap warga negara indonesia untuk melakukan pencatatan perkawinan agar hak-hak anak dapat terjamin dengan baik. Metodelogi yang di gunakan adalah yuridis normatif, hasil penelitian yaitu masih banyak masyarakat Indonesia yang belum memahami ketentuan umum tentang keharusan pencatatan dan juga belum memahami akibat hukum yang akan terjadi pada pihak yang melakukan perkawinan di bawah tangan tersebut.
\end{abstract}

Kata kunci: Perkawinan Di Bawah Tangan, Akibat Hukum

\begin{abstract}
Marriage is a sacred part of life, because it must pay attention to norms and rules in society. But for various reasons, marriage is often done in a variety of models of marriage. Like an underhand marriage. An underhand marriage is a marriage that has fulfilled the harmony and conditions of the marriage but has not stated the marriage to the competent authority as stipulated in the legislation. The purpose of this study is to reveal the legal consequences of the marriage results under the hand of his wife, children and property from Islamic Law and Law Number 1 of 1974 concerning Marriage in the hope that awareness of every Indonesian citizen arises to register marriages so that children's rights can well guaranteed. The methodology used is normative juridical, the results of research are that there are still many Indonesian people who do not understand the general provisions regarding the recording requirements and also do not understand the legal consequences that will occur to those who do the marriage under the hand.
\end{abstract}

Keywords: Marriage Under the Hand, Legal Effects

\section{PENDAHULUAN}

Allah telah menciptakan manusia pertama terdiri dari laki-laki dan perempuan sebagai suami istri yaitu Adam dan Hawa. Dari hasil perkawinan antara Adam dan Hawa inilah melahirkan manusia yang berkembang secara turun menurun dari generasi ke generasi melalui suatu perkawinan. Istilah kawin tidak hanya berlaku pada manusia, tetapi juga terjadi pada hewan dan bahkan juga terjadi pada tumbuh tumbuhan. Untuk membedakan perkawinan antara hewan dan manusia terletak pada adanya tujuan dan aturan pelaksanaan perkawinan. Pasal 1 Undang - Undang Nomor 1 Tahun 1974 Tentang Perkawinan mengatur bahwa; Perkawinan ialah ikatan lahir bathin antara seorang pria dengan seorang wanita sebagai suami istri dengan tujuan membentuk keluarga (rumah tangga) yang bahagia dan kekal berdasarkan Ketuhanan Yang Maha Esa. Didalam ketentuan pasal-pasal yang tedapat didalam KUHPdt, tidak memberikan pengertian mengenai perkawinan. Perkawinan Menurut kompilasi hukum Islam Pasal 2 diatur perkawinan menurut hukum Islam adalah pernikahan, yaitu akad yang sangat kuat atau mitsaqan ghalidzan untuk mentaati perintah Allah dan melaksanakanya merupakan ibadah.

Disamping pengertian tersebut diatas, terdapat pula pengertian perkawinan menurut Para Ahli, yaitu:

a. Menurut Wirjono Prodjodikoro, perkawinan adalah hidup bersama antara seorang laki-laki dan seorang perempuan yang memenuhi syarat-syarat termasuk dalam peraturan hukum perkawinan.

b. Menurut Subekti, S.H. perkawinan adalah pertalian yang sah antara seorang lelaki dan seorang perempuan untuk waktu yang lama.

\footnotetext{
${ }^{1}$ Dosen Fakultas Hukum Universitas Batanghari Jambi

${ }^{2}$ Mahasiswa Fakultas Hukum Universitas Batanghari Jambi
} 
Nurhasan dan Fitri Yani, Akibat Hukum Perkawinan di Bawah Tangan terhadap Istri, Anak, dan Harta Kekayaan dalam Perspektif Hukum Islam dan Undang-Undang Nomor 1 Tahun 1974 Tentang Perkawinan

c. Menurut Paul Scholten, perkawinan adalah hubungan hukum antara seorang pria dan seorang wanita untuk hidup bahagia dan kekal dan diakui oleh negara. ${ }^{3}$

Dalam perspektif Islam, perkawinan merupakan sunnatullah atas penciptaan manusia yang berpasangpasangan. ${ }^{4}$ Dan ia menjadi sebuah pertemuan antara dua individu dan dua keperibadian yang berbeda, sebagaimana yang disebutkan dalam firman Allah SWT :

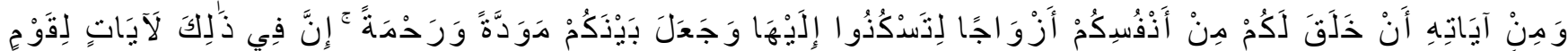

$$
\begin{aligned}
& \text { يَتَفَكَكَّرُونَ آنَانَ }
\end{aligned}
$$

"Dan di antara tanda-tanda Kekuasaan-Nya ialah Dia menciptakan untukmu isteri-isteri dari jenismu sendiri, supaya kamu cenderung dan merasa tenteram kepadanya, dan dijadikan-Nya diantaramu rasa kasih dan sayang. Sesungguhnya pada yang demikian itu benar-benar terdapat tanda-tanda bagi kaum yang berfikir. (Surat Ar-Rum Ayat 21)". 5

Pengetian Perkawinan dalam Islam adalah suatu perbuatan yang disuruh oleh Allah dan juga disuruh oleh Nabi. ${ }^{6}$ Perkawinan juga merupakan bagian hidup yang sakral, karena harus memperhatikan norma kaidah dalam bermasyarakat. Namun karena berbagai macam alasan, perkawinan sering dilakukan dalam berbagai macam model Pernikahan. Seperti Perkawinan di bawah tangan.

Menurut Fatwa MUI Nomor 10 Tahun 2008 Pernikahan dibawah tangan adalah Pernikahan yang terpenuhi semua rukun dan syarat yang di tetapkan dalam fiqh (hukum Islam) namun tanpa pencatatan resmi di instansi berwenang sebagaimana diatur dalam Peraturan Perundang-Undangan. ${ }^{7}$

Dari aspek penikahannya, menurut hukum Islam jika perkawinan itu telah memenuhi syarat sah dan rukun pernikahan, maka pernikahan adalah sah. Namun jika menurut hukum perkawinan yang berlaku di Indonesia, selain sah menurut agama dan kepercayaanya, suatu penikahan akan ada kekuatan hukum bila dicatat berdasarkan peraturan perundang-undangan yaitu di Kantor Urusan Agama (KUA) bagi warga muslim dan di Kantor Catatan Sipil (KCS) bagi warga non muslim.

Mengenai syarat sah perkawinan diatur dalam Pasal 2 ayat (1) Undang-Undang Nomor 1 Tahun 1974 Tentang Perkawinan yang mengatur: Perkawinan adalah sah apabila dilakukan menurut hukum masing - masing agamanya dan kepercayaannya.

Perkawinan yang telah dilangsungkan menurut hukum agama dan kepercayaan harus dicatat oleh petugas pencatat dengan maksud agar terjadi tertib administrasi pemerintahan dan kependudukan. Terciptanya tertib administrasi kependudukan berarti menghindarkan kekacauan administrasi yang berhubungan dengan kepastian kedudukan hukum seseorang.

Pekawinan di bawah tangan bagi umat Islam di Indonesia masih terjadi bukan saja dilakukan oleh kalangan masyarakat bawah, tapi juga oleh lapisan masyarakat menengah keatas. Sebut saja kasus nikah dibawah tangan penyanyi dangdut Aisyah Mochtar Alias Machica Mochtar.

Menurut H. M. Anshary, faktor penyebab seseorang yang melakukan perkawinan tetapi tidak mencatatkan perkawinannya dilembaga pencatat formal yaitu karena faktor biaya alias tidak mampu membayar administrasi pencatatan yang di nilai terlalu tinggi; ada pula yang disebabkan karena takut ketahuan melanggar aturan disiplin pegawai bagi pegawai negeri karena ada aturan yang melarang pegawai negeri nikah lebih dari satu; ada yang karena takut ketahuan istrinya dan lain sebagainya. ${ }^{8}$

Dalam fatwa MUI tentang pernikahan dibawah tangan juga mengesahkan pernikahan ini. Dalam ketentuan hukumnya Fatwa MUI No 10 Tahun 2008 Tentang Nikah Dibawah Tangan memutuskan bahwa “ Pernikahan dibawah tangan hukumnya sah karena terpenuhi syarat \& rukun nikah, tetapi haram jika terdapat

\footnotetext{
${ }^{3}$ A.Thalib,SH,MH., 2016, Diktat Hukum Perkawinan, Halaman - 03

${ }^{4}$ Surat An-Najm Ayat 45

${ }^{5}$ Departemen Agama Republik Indonesia, 2013, Alqur"an dan Terjemahannya, Penerbit PT Insan Media Pustaka : Jakarta hal - 406

${ }^{6}$ Amir Syarifuddin, 2009, Hukum Pekawinan Islam Di Indonesia, Penerbit Prenada Media Group, Jakarta, Hal 43

${ }^{7}$ Fatwa MUI Nomor 10 Tahun 2008 Tentang Pernikahan di Bawah Tangan halaman - 531

${ }^{8}$ H.M.Anshary, MK, SH., MH., 2014, Kedudukan Anak Dalam Perspektif Hukum Islam dan Hukum Nasional Penerbit Cv Mandar Maju : Palangkaraya, halaman 127-128
} 
madharrat". Selain itu MUI juga menekankan bahwa pernikahan harus dicatatkan secara resmi pada instansi berwenang sebagai langkah preventif untuk menolak dampak negative/madharrat. ${ }^{9}$

Perkawinan di bawah tangan biasanya dilakukan di hadapan tokoh masyarakat, ulama, atau ustadt sebagai penghulu, atau ada juga yang dilakukan secara adat-istiadat saja kemudian tidak dilaporkan kepada pihak yang berwewenang untuk dicatatkan sesuai dengan amanat pasal 2 ayat 2 Undang- Undang Nomor 1 tahun 1974 Tentang Perkawinan.

Sebagai masyarakat yang taat akan aturan harus dapat dipahami bahwa pentingnya pencatatan perkawinan dan akta nikahnya merupakan ketentuan yang perlu diterima dan dilaksanakan oleh penduduk yang mendiami wilayah Negara Republik Indonesia.

Menurut Achmad Nurseha bahwa alasan pentingnya pencatatan perkawinan adalah:

1. Mentaati perintah agama dan mentaati perintah negara/pemerintah, adalah wajib dalam AlQur'an surat An-Nisaa" ayat 59 Perintah al-Qur'an ini sangat positif, karena mendidik manusia untuk menciptakan masyarakat yang sadar dan taat hukum agama dan hukum negara, demi terwujudnya kesejahteraan dan kebahagiaan hidupnya di dunia dan akhirat.

2. Akta nikah sebagai bukti otentik sahnya perkawinan seseorang adalah sangat bermanfaat dan maslahah bagi dirinya dan keluarganya (isteri dan anaknya) untuk menolak kemungkinan di kemudian hari adanya pengingkaran atas perkawinannya dan akibat hukum dari perkawinannya itu (harta bersama dalam perkawinan dan kewarisannya), serta juga untuk melindunginya dari fitnah dan tuhmah/qadzaf zina (tuduhan zina). Maka jelaslah pencatatan nikah untuk mendapatkan akta itu penting untuk maslahah mursalah. ${ }^{10}$ Pemikiran itu didasari oleh metodologis asas yang kuat, Allah Berfirman dalam Al-Qur'an yang berkaitan dengan mursalah dan maslahah (Surah Al-Baqarah (2) ayat 282).

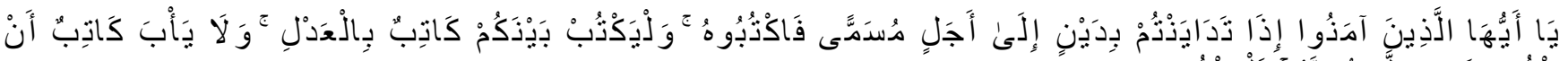

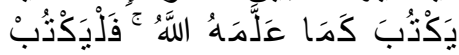

"Hai orang-orang yang beriman, apabila kamu bermu'amalah tidak secara tunai untuk waktu yang ditentukan, hendaklah kamu menuliskannya. Dan hendaklah seorang penulis di antara kamu menuliskannya dengan benar. Dan janganlah penulis enggan menuliskannya sebagaimana Allah mengajarkannya, maka hendaklah ia menulis". ${ }^{11}$

Salah satu tujuan perkawinan adalah untuk memperoleh keturunan berupa anak sebagaimana dalam Undang-Undang Dasar Republik Indonesia Tahun 1945 yang mengatur tentang hak asasi manusia dalam Pasal 28 B ayat 1 dan 2 mengatur Setiap orang berhak membentuk keluarga dan melanjutkan keturunan melaui perkawinan yang sah dan setiap anak berhak atas kelangsungan hidup, tumbuh, dan berkembang serta berhak atas perlindungan dari kekerasan dan diskriminasi.

Berdasarkan Undang - Undang Dasar Tahun 1945 Tentang Hak Asasi Manusia di atas dapat dijelaskan bahwa setiap anak juga memiliki hak dalam keluarga yaitu hak mendapatkan perlindungan, hak mendapatkan pendidikan, dan hak untuk mendapatkan warisan.

Dari beberapa contoh kasus diatas dapat diambil analisis sementara penulis bahwa sampai saat ini masih terjadi perkawinan dibawah tangan, hal ini terjadi karena belum memahami ketentuan hukum tentang keharusan perkawinan di catat oleh pejabat yang berwenang berdasarkan Undang-Undang Nomor 1 Tahun 1974 Pasal 2 Ayat 2 Tentang Perkawinan. Juga belum memahami akibat hukum yang akan terjadi oleh para pihak yang terikat dalam perkawinan tersebut baik bagi istri maupun anak yang dihasilkan dari perkawinan dibawah tangan tersebut.

Oleh karena itu peneliti akan mengungkapkan akibat hukum hasil perkawinan dibawah tangan terhadap istri, anak dan harta kekayaan dari Hukum Islam dan Undang-Undang Nomor 1 Tahun 1974

\footnotetext{
${ }^{9}$ Fatwa MUI op-cit Halaman 531
}

${ }^{10}$ Achmad Nurseha, 2015, Tinjauan Hukum Islam Terhadap Praktik Nikah Dibawah Tangan (Studi Kasus Di Kecamatan Ngawen Kabupaten Blora Jurusan Ahwal Al-Syakhshiyyah Fakultas Syari’ah Universitas Islam Negeri Walisongo, Semarang, Halaman 78-79

${ }^{11}$ Departemen Agama Republik Indonesia, Alqur"an dan Terjemahannya, op-cit hal 48 
Nurhasan dan Fitri Yani, Akibat Hukum Perkawinan di Bawah Tangan terhadap Istri, Anak, dan Harta Kekayaan dalam Perspektif Hukum Islam dan Undang-Undang Nomor 1 Tahun 1974 Tentang Perkawinan

Tentang Perkawinan dengan harapan agar timbul kesadaran setiap warga negara indonesia untuk melakukan pencatatan perkawinan agar hak-hak anak dapat terjamin dengan baik.

Berdasarkan latar belakang yang uraikan di atas maka rumusan masalah sebagai berikut :

1. Bagaimanakah Akibat Hukum Perkawinan Di Bawah Tangan Terhadap Istri Dalam Perspektif Hukum Islam Dan Undang-Undang Nomor 1 Tahun 1974 Tentang Perkawinan.

2. Bagaimanakah Akibat Hukum Perkawinan Di Bawah Tangan Terhadap Anak Dalam Perspektif Hukum Islam Dan Undang-Undang Nomor 1 Tahun 1974 Tentang Perkawinan.

3. Bagaimanakah Akibat Hukum Perkawinan Di Bawah Tangan Terhadap Harta Kekayaan Dalam Perspektif Hukum Islam Dan Undang-Undang Nomor 1 Tahun 1974 Tentang Perkawinan

\section{METODE PENELITIAN}

Penelitian ini menggunakan metode penelitian yuridis normatif yaitu penelitian hukum yang dilakukan dengan cara meneliti bahan pustaka atau data sekunder sebagai bahan dasar untuk diteliti dengan cara mengadakan penelusuran terhadap peraturan-peraturan dan literatur-literatur yang berkaitan dengan permasalahan yang diteliti.

\section{HASIL DAN PEMBAHASAN}

\section{Akibat Hukum Perkawinan Di Bawah Tangan Terhadap Istri Menurut Hukum Islam Dan Undang- Undang Nomor 1 Tahun 1974 Tentang Perkawinan.}

Dalam hukum Islam, perkawinan di bawah tangan menurut hukum Islam adalah sah karena telah tepenuhi rukun dan syarat suatu perkawinan, walaupun tidak di daftarkan atau di catatkan pada kepala kantor urusan agama (KUA). Pencatatan perkawinan hanya bersifat administratif, sehingga perkawinan yang tidak di catat oleh petugas pencatatan nikah, perkawinan yang di maksud tetap sah. Perkawinan di bawah tangan sah menurut hukum Islam, maka semua akibat hukum dari perkawinan yang sah menjadi sah.

Sebagai mana kita ketahui MUI telah mengeluarkan fatwa tentang nikah di bawah tangan, bahwa perkawinan di bawah tangan hukumnya sah karena terpenuhi syarat dan rukun nikah, tetapi menjadi haram jika terdapat kemudhratan di dalamnya. Mengingat dalam firman Allah telah di jelaskan dalam Q.S Al-Rum ayat 21 yang artinya: Dan di antara tanda-tanda Kekuasaan-Nya ialah Dia menciptakan untukmu isteri-isteri dari jenismu sendiri, supaya kamu cenderung dan merasa tenteram kepadanya, dan dijadikan-Nya diantaramu rasa kasih dan sayang. Sesungguhnya pada yang demikian itu benar-benar terdapat tanda-tanda bagi kaum yang berfikir Perkawinan di bawah tangan yang terjadi di Indonesia ini tetap di pandang sah dalam perspektif hukum Islam apabila telah terpenuhi rukun dan syaratnya, tetapi akad ini dapat menimbulkan dampak atau akibat hukum yang sangat merugikan bagi istri dan anak-anaknya.

Dampak yang terlihat yaitu Secara sosial, isteri akan sulit bersosialisasi dengan masyaakat setempat dan berakibat akan mengurangi hak-hak sipil mereka sebagai warga negara. Mereka rentan untuk dipermainkan oleh laki-laki yang tidak bertanggung jawab karena mereka tidak memiliki kekuatan hukum untuk menggugat, mudah ditelantarkan, tidak diberi nafkah dengan cukup dan tidak ada kepastian status dari suami, karena nikah sirri tidak diakui oleh hukum. Dampak sosial lainnya, biasanya sebuah perkawinan di bawah tangan akan dinilai masyarakat sebagai sebuah perkawinan yang tidak ideal dan tidak membuat suasana rumah tangga harmonis. ${ }^{12}$

Menurut undang-undang nomor 1 tahun 1974 tentang perkawinan akibat yang akan di timbul kan dari perkawinan di bawah tangan terhadap istri yaitu:

1. Istri tidak mempunyai kekuatan hukum yang tetap terhadap legalitas perkawinan tersebut, sehingga apabila adanya hak-hak istri yang dilanggar oleh suami, istri tidak dapat menuntut hak-hak tersebut secara hukum ke pengadilan;

2. Istri tidak mendapatkan perlindugan hukum dari negara di karenakan tidak adanya pencatatan yang di lakukan di hadapan pegawai pencatatan nikah

3. Istri tidak memiliki akta nikah yang menyatakan bawha istri telah melakukan perkawinan.

${ }^{12}$ Abdullah Wasian, 2010, Akibat Hukum Perkawinan Siri Terhadap Kedudukan Istri Dan Anak Dan Harta Kekayaannya Tinjauan Hukum Islam Dan Undang-Undang Perkawinan, Tesis Program Studi Magister Kenotariatan Program Pascasarjana Universitas Di Ponegoro, Semarang : Halaman 161 
4. Istri tidak bisa mengurus Kartu Tanda Penduduk (KTP), atau Kartu Keluarga (KK) Di karena kan tidak adanya bukti yang autentik berupa akta nikah.

Berdasarkan uraian di atas dapat kita simpulkan beberapa akibat dari perkawinan di bawah tangan, walaupun akad nikah di bawah tangan dalam agama Islam dipandang sebagai akad nikah yang sah, asalkan terpenuhi rukun dan syaratnya, tetapi akibat yang timbul dari perkawinan di bawah tangan, lebih besar kemudaratannya daripada kemaslahatannya. maka perkawinan di bawah tangan hanya menguntungkan suami/laki-laki dan akan merugikan kaum perempuan dan anak-anak. Pencatatan pernikahan atau pembuatan akta pernikahan, secara syariat, bukanlah rukun atau syarat yang menentukan sahnya pernikahan. Namun adanya bukti autentik yang tertulis dapat menjadi salah satu alat memperkuat komitmen yang dibangun oleh pasangan tersebut. Walaupun memperkuat komitmen tidak terbatas pada aktanya, karena akta sendiri bisa dibatalkan melalui gugatan perceraian. Adapun penyelesaian permasalahan yang ditimbulkan akibat perkawinan di bawah tangan dapat diselesaikan dengan diajukan permohonan penetapan perkawinan (Isbat Nikah) di Pengadilan Agama.

\section{Akibat Hukum Perkawinan Di Bawah Tangan Terhadap Anak Menurut Hukum Islam Dan Undang- Undang Nomor 1 Tahun 1974 Tentang Perkawinan}

Dalam hukum Islam anak yang di lahirkan dari perkawinan di bawah tangan adalah anak sah. Seorang anak sah ialah anak yang di anggap lahir di antara perkawinan yang sah antara ayah dan ibunya. karena perkawinan tersebut telah memenuhi rukun dan syarat yang telah di tentukan dalam Islam dan perkawinan tersebut juga telah memenuhi ketentuan Pasal 2 ayat 1 Undang-Undang Perkawinan. Kedudukan Anak yang lahir dari perkawinan ini dalam Islam berhak mendapat kan pengakuan dari ayahnya dan keluarga ayahnya serta mendapat hak waris dan nafkah dari prang tuanya. Selain itu anak juga berhak mendapatkan pemeliharaan, pengasuhan, pendidikan, penjagaan, dan perlindungan dari orang tuanya, sebagaimana firman Allah dalam Al-Quran dalam surah Al-Baqaroh ayat 233 yang artinya: Para ibu hendaklah menyusukan anak-anaknya selama dua tahun penuh, yaitu bagi yang ingin menyempurnakan penyusuan. Dan kewajiban ayah memberi makan dan pakaian kepada para ibu dengan cara ma'ruf. Seseorang tidak dibebani melainkan menurut kadar kesanggupannya. Janganlah seorang ibu menderita kesengsaraan karena anaknya dan seorang ayah karena anaknya, dan warispun berkewajiban demikian. Apabila keduanya ingin menyapih (sebelum dua tahun) dengan kerelaan keduanya dan permusyawaratan, maka tidak ada dosa atas keduanya. Dan jika kamu ingin anakmu disusukan oleh orang lain, maka tidak ada dosa bagimu apabila kamu memberikan pembayaran menurut yang patut. Bertakwalah kamu kepada Allah dan ketahuilah bahwa Allah maha melihat apa yang kamu kerjakan.

Namun dalam peraturan perundang-undangan Perkawinan di bawah tangan banyak sekali mendatangkan kerugian dari pada kebaikan terutama terhadap anak yang akan di lahirkan. Sebab apabila anak itu di lahirkan dari perkawinan yang tidak di catatkan pada kantor pencatatan perkawinan, maka akan susah untuk mengurus masalah administrasi anak, misalnya dalam mengurus akta kelahiran si anak. Karena dalam perkembangan dewasa ini banyak lembaga pendidikan dari taman kanak-kanak sampai perguruan tinggi, telah menetapkan adanya akta kelahiran sebagai salah satu syarat untuk di terima di lembaga pendidikan yang bersangkutan. Contoh problem hukum dari perkawinan di bawah tangan adalah mengenai bentuk perlindungan Negara kepada pasangan suami istri bila terjadi sengketa perkawinan tersebut. Sebagaimana kita ketahui anak yang di lahirkan dari perkawinan di bawah tangan adalah perkawinan yang memenuhi norma Agama akan tetapi tidak memenuhi norma hukum. Mengapa demikian di karenakan perkawinan tersebut telah memenuhi syarat dan rukun nikah secara agama Islam yang di anut oleh orang tua si anak, hanya saja perkawinan tersebut tidak di lakukan di hadapan pegawai pencatatan nikah dan tidak di catatkan.

Anak yang lahir dari perkawinan bawah tangan hanya memenuhi rukun serta syarat perkawinan yang di tentukan oleh agama dan kepercayaan masing-masing (syarat materil dalam Pasal 2 ayat 1 UndangUndang Nomor 1 Tahun 1974). Akan tetapi tidak di catatkan pada instansi yang berwenang untuk itu sebagaimana dalam Pasal 2 Ayat 2 Undang-Undang Nomor 1 Tahun 1974 yang mengatur, bahwa tiap-tiap perkawinan mesti di catat menurut peraturan perundang-undangan yang berlaku (syarat formal). Dan dalam kompilasi hukum Islam Pasal 6 ayat 2 juga mengatur bahwa perkawinan yang di lakukan di luar pengawasan pegawai pencatatan nikah tidak mempunyai kekuatan hukum. 
Dalam perlindungan hukum yang di berikan negara kepada anak tersebut, seperti hak menuntut warisan dari peninggalan bapaknya, oleh karena hubungan antara anak dengan bapak kandungnya tidak di dukung oleh bukti yang otentik berupa akta nikah orang tuanya, maka secara formil ia tidak dapat mengajukan gugatan waris melalaui lembaga formal negara yakni lembaga Peradilan.

Ketidakjelasan status anak di muka hukum, mengakibatkan hubungan antara ayah dan anak tidak kuat, sehingga bisa saja, suatu waktu ayahnya menyangkal bahwa anak tersebut adalah anak kandungnya. Yang jelas merugikan adalah anak tidak berhak atas biaya kehidupan dan pendidikan, nafkah dan warisan dari ayahnya.

Seorang anak yang sah menurut undang-undang yaitu hasil perkawinan yang sah. Ini tercantum dalam Undang-Undang Nomor 1 Tahun Perkawinan, pasal 42 ayat 1 : anak yang sah adalah anak-anak yang di lahirkan dalam atau sebagai akibat perkawinan yang sah. Namun status anak hasil perkawinan di bawah tangan karena tidak di catatkan oleh negara maka status anak di katakan di luar nikah. ${ }^{13}$ Secara agama status anak hasil dari perkawinan ini mendapatkan hak sama dengan anak hasil perkawinan yang di catatkan berdasarkan agama yang tidak selaras dengan hukum yang berlaku di Indonesia. Hal ini bertentangan dengan perundang-undangan yang di atur dalam Undang-Undang Nomor 1 Tahun 1974 Tentang Perkawinan Pasal 43 ayat 1 yaitu anak yang di lahirkan di luar perkawinan hanya mempunyai hubungan perdata dengan ibunya dan keluarga ibunya.

Berdasarkan uraian di atas, hubungan anak dengan seorang laki-laki sebagai bapak tidak semata-mata karena adanya ikatan perkawinan, akan tetapi dapat juga didasarkan pada pembuktian adanya hubungan darah antara anak dengan laki-laki tersebut sebagai bapak. Dengan demikian, terlepas dari soal prosedur/administrasi perkawinannya, anak yang dilahirkan harus mendapatkan perlindungan hukum. Jika tidak demikian, maka yang dirugikan adalah anak yang dilahirkan dari perkawinan di bawah tangan, padahal anak tersebut tidak berdosa karena kelahirannya di luar kehendaknya. Anak yang dilahirkan tanpa memiliki kejelasan status ayah seringkali mendapatkan perlakuan yang tidak adil dan stigma di tengah-tengah masyarakat. Hukum harus memberi perlindungan dan kepastian hukum yang adil terhadap status seorang anak yang dilahirkan dan hak-hak yang ada padanya, termasuk terhadap anak yang dilahirkan meskipun keabsahan perkawinannya masih dipersengketakan.

\section{Akibat Hukum Perkawinan Di Bawah Tangan Terhadap Harta Kekayaan Menurut Hukum Islam Dan Undang-Undang Nomor 1 Tahun 1974 Tentang Perkawinan.}

Hakekat dan tujuan perkawinan dalam Islam sebenarnya bermuara kepada ibadah untuk menciptakan keluarga bahagia sakinah, mawaddah, warahmah yang diridoi Allah SWT di dunia dan akherat. Bahkan perkawinan harus dipertahankan hingga ajal kematian menjemputnya. Namun demikian manusia hanya merencanakan, Tuhan yang menentukan dalam setiap perjalanan hidup setiap makhluk-Nya termasuk mahligai dan liku-liku rumah tangga hamba-Nya. Dalam perkawinan putusnya perkawinan di akibatkan adanya kematian, perceraian atau putusan pengadilan.

Perkawinan mempunyai akibat hukum tidak hanya terhadap diri pribadi mereka-mereka yang melangsungkan pernikahan, hak dan kewajiban yang mengikat pribadi suami isteri, tetapi lebih dari itu mempunyai akibat hukum pula terhadap harta suami isteri tersebut. Hubungan hukum kekeluargaan dan hubungan hukum kekayaannya terjalin sedemikian eratnya, sehingga keduanya memang dapat dibedakan tetapi tidak dapat dipisahkan. Hubungan hukum kekeluargaan menentukan hubungan hukum kekayaannya dan hukum harta perkawinan tidak lain merupakan hukum kekayaan keluarga.

Setiap perkawinan, masing-masing pihak dari suami atau isteri mempunyai harta yang dibawa dan diperoleh sebelum melakukan akad perkawinan. Suami atau isteri yang telah melakukan perkawinan mempunyai harta yang diperoleh selama perkawinan yang disebut harta bersama. Meskipun harta bersama tersebut hanya suami yang bekerja dengan berbagai usahanya sedangkan isteri berada di rumah dengan tidak mencari nafkah melainkan hanya mengurus rumah tangga dan anak-anaknya. ${ }^{14}$

Dalam Islam tidak di kenal harta bersama kecuali dengan syirqah (kerja sama) karena harta bersama merupakan persoalan hukum yang belum di sentuh atau terpikirkan oleh ulama-ulama fiqh terdahulu karena

\footnotetext{
${ }^{13}$ Www.Https://Jabar.Tribunnews.Com Di Akses Pada Hari Kamis Tanggal 17 Januari 2019 Pukul 15: 29 Wib

${ }_{14}$ Mohd. Idris Ramulyo, 1996, Hukum Perkawinan Islam, Penerbit PT Bumi Aksara : Jakarta hal. 231-232.
} 
masalah harta bersama baru muncul dan banyak di bicarakan dalam masa modern ini. Hukum Islam mengatur sistem terpisahnya harta suami dan harta istri sepanjang yang bersangkutan tidak menentukan dalam perjanjian perkawinan. Hukum Islam juga memberikan kelonggaran kepada mereka berdua untuk membuat perjanjian perkawinan sesuai dengan keinginan mereka berdua, dan perjanjian tersebut akhirnya mengikat mereka secara hukum.

Harta bersama antara suami isteri baru dapat dibagi apabila hubungan perkawinan itu sudah terputus. Hubungan perkawinan itu dapat terputus karena kematian, perceraian dan dapat pula oleh keputusan Pengadilan. Apabila terjadi putus hubungan perkawinan baik karena cerai atas gugatan pihak isteri, atau karena talak atas permohonan suami maka harta bersama itu harus dibagi 50:50 antara suami isteri itu.

Dalam pembahasan ini yang menjadi permasalahan adalah akibat hukum yang di timbulkan apabila perkawinan di bawah tangan terjadi perceraian dalam hukum Islam perkawinan dibawah tangan di anggap sah karena telah memenuhi rukun dan syarat perkawinan maka jika terjadi perceraian maka harta yang di peroleh dalam perkawinan itu tetap di bagi $1 / 2$ untuk suami dan $1 / 2$ untuk istri dan anak adalah tanggungan dari kedua orang tuannya, namun jika suami meninggal dunia dan dalam perkawinan mereka tidak di karunia seorang anak istri mendapatkan $1 / 2$ harta peninggalan suami, namun jika mereka memilki seorang anak maka istri mendapatkan 1/8 dari harta yang di tinggalkan suaminya.

Jika kita lihat dalam hukum negara akibat dari perkawinan di bawah tangan yang tidak di catatkan pada Kantor Urusan Agama, maka perkawinan ini sangat berdampak bagi istri apabila terjadi percekcokan di dalam rumah tangga baik dari segi hak asuh anak, warisan dan harta bersama. Perkawinan yang tidak dianggap sah didalam pemerintahan, apabila terjadi sengketa yang terjadi antara kedua belah pihak sehingga ingin bercerai, maka pengadilan tidak dapat mengabulkan gugatan cerai tersebut, di karenakan perkawinannya tidak di catatkan di awal. Dari sisi lain, apabila di lihat dari penyelesaian masalahnya, maka semua permasalahan yang terjadi di dalam perkawinan tersebut tidak dapat di selesaikan melalui jalur peradilan di karenakan mereka tidak dapat memenuhi syarat administrasi seperti buku nikah, kartu keluarga, dan lain sebagainya. Wanita yang menikah akan tetapi perkawinan nya tidak di catatkan, maka dia tidak bisa memiliki separuh dari harta bersama yang di peroleh selama melakukan perkawinan. Hal ini di sebabkan perkawinan tersebut tidak tercatat secara resmi oleh Negara dan permasalahan tersebut tidak dapat di selesaikan di dalam peradilan. Sebagaimana di atur dalam Pasal 5 ayat 1 Kompilasi Hukum Islam bahwa pencatatan perkawinan bukan sebagai syarat sah perkawinan tetapi sebagai alat untuk menciptakan ketrtiban perkawinan. Oleh karena itu, perkawinan yang tidak tercatat tidak memliki kekuatan hukum sehingga keabsahannya di ragukan.

Menghadapi permasalahan perkawinan di bawah tangan, Hal ini untuk menghindarkan terjadinya ketidakadilan dalam masalah pembagian harta. Sehingga bagi Perkawinan di bawah tangan, dalam melakukan perceraian hendaknya mengajukan permohonan Itsbat Nikahnya terlebih dahulu kepada Pengadilan Agama, baru kemudian melakukan proses cerai secara hukum yang berlaku. Pengaturan mengenai Itsbat Nikah telah ditegaskan dalam Kompilasi Hukum Islam Pasal 7, khususnya pada Ayat (3) sub (a) yang menyatakan : Itsbat Nikah dapat diajukan dalam hal adanya perkawinan dalam rangka penyelesaian perceraian.

Begitu juga halnya apabila suami meninggal dunia dan meninggalkan harta kekayaan nya maka akibat yang di dapatkan oleh istri dari hasil perkawinan di bawah tangan tidak dapat mengajukan tuntutan tentang adanya harta bersama ke pengadilan karena tidak memenuhi syarat formil yang telah di tentukan ataupun perkawinan tersebut tidak di catatkan di KUA. Sebab di dalam hukum negara perkawinan tersebut tidak memiliki kekuatan hukum yang kuat sehingga harta suami tersebut akan di bagikan kepada keluarga sahnya menurut garis keturunan yang sah, Di zaman sekarang ini jika seseorang menuntut ia harus mempunyai bukti dan bukti itu harus tertulis, tercatat, terdaftar. ${ }^{15}$ Penyebab ini sangat berdampak merugikan bagi pihak istri dan anaknya di kemudian hari.

Lalu bagaimana istri mendapatkan hak jika suami meninggal dunia dan meninggalkan banyak harta maka jawabannya adalah istri mendapatkan harta warisan $1 / 2$ bagian dari harta suami yang menikahinya karena dalam Islam sah apabila perkawinan telah terpenuhi rukun dan syarat perkawinan, namun istri tidak

${ }^{15}$ Muhammad Syaifuddin, 2012, Hukum Perceraian, Sinar Grafika, Jakarta : Halaman 271 
Nurhasan dan Fitri Yani, Akibat Hukum Perkawinan di Bawah Tangan terhadap Istri, Anak, dan Harta Kekayaan dalam Perspektif Hukum Islam dan Undang-Undang Nomor 1 Tahun 1974 Tentang Perkawinan

mendapatkan harta warisan jika harta tersebut di peroleh dari hasil yang berkaitan dengan pemerintahan salah satunya hasil pensiun suami atau pun harta yang terdaftar dalam pajak negara.

Jika seandainya suatu hari setelah perceraian dan istri yang sudah di cerai (talaq) atau cerai mati oleh suami dari perkawinan di bawah tangan, lalu istri akan menikah lagi dan perkawinan itu di catat di Kantor Urusan Agama maka mantan suami tidak dapat mempersengketakan lagi harta yang ada pada mantan istri tersebut di karenakan mereka telah bercerai dan mereka juga telah memiliki masing-masing bagiannya.

Dan bagaimanakah akibat harta kekayaan terhadap anak yang di hasilkan dari perkawinan di bawah tangan apabila ayah dan ibunya bercerai atau pun ayahnya meninggal dunia, jawabannya adalah perkawinan yang tanpa adanya pencatatan tersebut, anak bisa saja menerima hak waris apabila mendapat pengakuan dari ayah kandungnya. Secara agama kedudukan anak di dalam hukum Islam tetap memperoleh pengakuan yang sama dengan perkawinan yang di catatkan, namun karena anak adalah anak yang di lahir kan dari perkawinan di bawah tangan yang di lakukan orang tuanya sebelum di sahkan oleh pengadilan agama, maka status anak tetap di anggap sebagai anak di luar perkawinan. ${ }^{16}$ maka anak yang lahir dari perkawinan di bawah tangan hanya memiliki hubungan hukum mewarisi dengan ibu kandungnya sebagaimana di atur dalam Pasal 43 Undang-Undang Perkawinan dan Pasal 186 Kompilasi Hukum Islam.

Merujuk pada kasus Perkawinan yang di lakukan oleh Aisyah Mochtar alias Machicha binti Mochtar Ibrahim dan mantan suaminya Moerdiono adalah perkawinan yang hanya memenuhi pasal 2 ayat $1 \mathrm{UU}$ Nomor 1 Tahun 1974 pada dasarnya perkawinan di Indonesia harus di laksanakan dengan prosedur sesuai dengan Pasal 2 ayat 1 dan 2 Undang-Undang Nomor 1 Tahun 1974 Tentang Perkawinan. Jika perkawinan di lakukan hanya mengikuti pasal 2 ayat 1 saja, maka perkawinan itu di sebut "luar perkawinan" oleh karena itu pasal 43 ayat 1 Undang-undang nomor 1 tahun 1974 Tentang Perkawinan itu tidak berdiri sendiri, sangat berkaitan dengan adanya perkawinan sebagaimana di atur oleh pasal 2 Undang-Undang Nomor 1 Tahun 1974 Tentang Perkawinan.

Dengan itu putusan Mahkamah Konstitusi Nomor: 46/PUU-VIII/2010 tanggal 27 Pebruari 2012 memutuskan Bahwa Pasal 43 Ayat 1 Undang-Undang Nomor 1 Tahun 1974 Tentang Perkawinan (Lembaran Negara Republik Indonesia Tahun 1974 Nomor 1, Tambahan Lembaran Negara Republik Indonesia Nomor. 3019) yang mengatur, "Anak yang dilahirkan di luar perkawinan hanya mempunyai hubungan perdata dengan ibunya dan keluarga ibunya", bertentangan dengan UUD Negara Republik Indonesia 1945, dan tidak mengikat sepanjang dimaknai menghilangkan hubungan perdata dengan laki- laki yang dapat dibuktikan berdasarkan ilmu pengetahuan dan teknologi dan/ atau alat bukti lain menurut hukum ternyata mempunyai hubungan darah sebagai ayahnya. Ayat tersebut harus dibaca:

"Anak yang dilahirkan di luar perkawinan mempunyai hubungan perdata dengan ibunya dan keluarga ibunya serta dengan laki- laki sebagai ayahnya yang dapat dibuktikan berdasarkan ilmu pengetahuan dan teknologi dan/atau alat bukti lain menurut hukum mempunyai hubungan darah termasuk hubungan perdata dengan keluarga ayahnya".

Maksudnya, anak luar kawin akan menjadi anak yang sah jika dibuktikan melalui ilmu pengetahuan dan teknologi sebagai anak dari ayahnya. Pembuktian melalui ilmu pengetahuan dan teknologi biasanya dengan melakukan tes golongan darah atau DNA (Deoksiribo Nuklead Acid). Tes DNA berguna untuk mengetahui apakah ada kesamaan golongan darah anak dengan ayah dan keluarga ayahnya atau tidak. Tes DNA berlaku sacara umum, baik untuk anak luar kawin yang dilahirkan dari pernikahan tidak dicatatkan, anak luar kawin dari hasil perzinahan, anak yang tidak diakui oleh ayahnya (li'an), anak yang tertukar, ataupun anak yang tidak diketahui asal-usul orang tuanya

Ketua Mahkamah Konstitusi ketika itu, Mahfud M.D., telah mengklarifikasi dengan menyatakan: "bahwa yang dimaksud majelis dengan frasa "anak di luar perkawinan" bukan anak hasil zina, melainkan anak hasil perkawinan tidak dicatatkan. ${ }^{17}$

${ }^{16}$ Https://Economy.Okezone.Com Di Akses Pada Hari Sabtu 19 Januari 2018 Pukul 18:57 Wib

17 Achmad Irwan Hamzani, 2015, Nasab Anak Luar Kawin Pasca Putusan Mahkamah Konstitusi Nomor 46/PUUVIII/2010, Jurnal Konstitusi, Volume 12, Nomor 1, Maret , jawa tengah : halaman 64 
Dari penjelasan di atas dapat di simpulkan bahwa harta kekayaan yang di hasilkan dari perkawinan yang tidak di catatkan secara resmi pada kantor pencatatan sipil akan berakibat buruk bagi istri ataupun anak yang di tinggalkan di karenakan istri tidak bisa menuntut haknya untuk memperoleh harta yang mereka miliki selama perkawinan tersebut. Dan istri juga tidak bisa membuktikan bahwa harta yang di tinggalkan suaminya adalah harta bersama yang di hasilkan dari perkawinan mereka di karenakan tidak adanya bukti yang otentik yang di miliki istri untuk dapat membuktikan semua itu. Untuk anak yang di lahirkan dari perkawinan di bawah tangan dengan adanya putusan MK maka anak mempunyai hubungan darah bukan saja dengan ibu dan keluarga ibunya melainkan dengan ayah dan juga keluarga ayahnya yang di dasari dengan bukti tes darah.

\section{SIMPULAN}

Berdasarkan hasil penelitian dan pembahasan yang telah di uraikan sebelumnya, maka dapat di ambil kesimpulan sebagai berikut:

1. Akibat hukum perkawinan di bawah tangan menurut hukum Islam terhadap istri ia tetap mendapatkan hak-haknya secara penuh dan menurut Undang-Undang Nomor 1 Tahun 1974 Tentang Perkawinan akibat hukum terhadap istri ia tidak mendapatkan hak-haknya secara penuh dan juga tidak mendapatkan perlindungan hukum dikarenakan tidak memiliki bukti yang autentik berupa akta nikah dan menjadikan istri sangat lemah dalam melakukan tindakan hukum yang berupa tuntutan dalam pengadilan.

2. Akibat hukum perkawinan di bawah tangan terhadap anak menurut hukum Islam ia tetap mendapatkan hak dan kewaiban dari orang tuanya dan tetap mendapat pengakuan dari orang tua biologisnya. Dan menurut Undang-Undang Nomor 1 Tahun 1974 Tentang Perkawinan akibat hukum terhadap anak yaitu anak tidak dapat memperoleh akta kelahiran dari ayah yang berwenang karena untuk memperoleh akta kelahiran itu di perlunya akta nikah dari orang tuanya dan anak tidak dapat memperoleh hak-hak dalam pelaksanaan administrasi negara yang mesti harus di penuhi sebagai bukti diri seperti KTP dan SIM .

3. Akibat hukum perkawinan di bawah tangan terhadap harta kekayaan menurut Islam yaitu istri tetap mendapatkan hak dan kedudukannya yakni berupa harta yang di peroleh dalam perkawinan atau pun hak mewarisi dari suaminya. Dan menurut Undang-Undang Nomor 1 Tahun 1974 Tentang Perkawinan akibat hukum terhadap harta kekayaan yaitu istri tidak mendapatkan hak dan kedudukannya dalam memperoleh harta kekayaan selama perkawinan dan tidak mendapatkan hak untuk mendapatkan warisan dari suami yang di tinggalkan kecuali suami mempunyai itikad baik untuk memberikan harta tersebut.

\section{DAFTAR PUSTAKA}

\section{Buku-Buku}

Amir Syarifuddin, 2009, Hukum Pekawinan Islam Di Indonesia, Penerbit Prenada Media Group : Jakarta.

A.Thalib, 2016, Diktat Hukum Perkawinan, Jambi.

Departemen Pendidikan Dan Kebudayaan, 1976, Kamus Besar Bahasa Indonesia Cet.V, Balai Pustaka, Jakarta

Mardani, 2010, Hukum Islam Pengantar Ilmu Hukum Islam Di Indonesia, Penerbit Pustaka Pelajar: Yogyakarta

M.Anshary, MK, 2014, Kedudukan Anak Dalam Perspektif Hukum Islam Dan Hukum Nasional, Penerbit Cv. Mandar Maju : Bandung.

Muhammad Syaifuddin, 2012, Hukum Perceraian, Sinar Grafika, Jakarta

Mohd. Idris Ramulyo, 1996, Hukum Perkawinan Islam, Penerbit PT Bumi Aksara : Jakarta.

Soerjono Soekanto 2001, Penelitian Hukum Normatif (Suatu Tinjauan Singkat), Rajawali Pers, Jakarta.

Zainuddin Ali, 2009, Metode Penelitian Hukum, Sinar Grafika : Jakarta.

\section{Jurnal-Jurnal lainnya}

Abdullah Wasian, 2010, Akibat Hukum Perkawinan Siri Terhadap Kedudukan Istri Dan Anak Dan Harta Kekayaannya Tinjauan Hukum Islam Dan Undang-Undang Perkawinan, Tesis Program Studi Magister Kenotariatan Program Pascasarjana Universitas Di Ponegoro, Semarang 
Nurhasan dan Fitri Yani, Akibat Hukum Perkawinan di Bawah Tangan terhadap Istri, Anak, dan Harta Kekayaan dalam Perspektif Hukum Islam dan Undang-Undang Nomor 1 Tahun 1974 Tentang Perkawinan

Achmad Nurseha : 2015, Tinjauan Hukum Islam Terhadap Praktik Nikah Dibawah Tangan (Studi Kasus Di Kecamatan Ngawen Kabupaten Blora Jurusan Ahwal Al-Syakhshiyyah) Skripsi Fakultas Syari'ah Universitas Islam Negeri Walisongo, Semarang.

Achmad Irwan Hamzani, 2015, Nasab Anak Luar Kawin Pasca Putusan Mahkamah Konstitusi Nomor 46/PUU-VIII/2010, Jurnal Konstitusi, Volume 12, Nomor 1, Maret , jawa tengah

\section{Peraturan Perundang-Undangan}

UUD 1945 Hasil Amandemen

Republik Indonesia Undang-Undang No 1 Tahun 1974 Tentang Perkawinan (Lembaran Negara Republik Indonesia Tahun 1974 No 1 )

Republik Indonesia Instruksi Presiden No 1 Tahun 1991 Tentang Kompilasi Hukum Islam

Fatwa MUI Nomor 10 Tahun 2008 Tentang Nikah Dibawah Tangan

\section{Website}

Https://Economy.Okezone.Com

Www.Https://Jabar.Tribunnews.Com 